\title{
Microwave-assisted Hydrothermal Synthesis of Magnetite Nanoparticles with Potential Use as Anode in Lithium Ion Batteries
}

\author{
Camila Soares Xavier ${ }^{a}$, Carlos Alberto Paskocimas ${ }^{b}$, Fabiana Villela da Motta $^{b}$, Vinícius Dantas Araújo ${ }^{b}$ \\ Maria José Aragón ${ }^{c}$, José Luís Tirado ${ }^{c}$, Pedro Lavelac, Elson Longo ${ }^{a}$, Mauricio Roberto Bomio Delmonte ${ }^{b *}$ \\ anstituto de Química, Universidade Estadual Paulista - UNESP, \\ CEP 14800-900, Araraquara, SP, Brazil \\ ${ }^{b}$ Laboratório de Síntese Química de Materiais - LSQM, Departamento de Engenharia de Materiais - \\ DEMat, Universidade Federal do Rio Grande do Norte-UFRN, \\ CP 1524, CEP 59078-970, Natal, RN, Brazil \\ ${ }^{c}$ Laboratorio de Química Inorgánica, Universidad de Córdoba, 14071 Córdoba, Spain
}

Received: January 17, 2014; Revised: August 21, 2014

\begin{abstract}
Rechargeable solid-state batteries have long been considered an attractive power source for a wide variety of applications, and in particular, lithium-ion batteries are emerging as the technology of choice for portable electronics. One of the main challenges in the design of these batteries is to ensure that the electrodes maintain their integrity over many discharge-recharge cycles. $\mathrm{Fe}_{3} \mathrm{O}_{4}$ deserves great attention as one of the most important electrode active materials due to its high theoretical capacity (926 mAhg ${ }^{-1}$ ), low cost, being environmental-friendly and naturally abundance in worldwide. A simple strategy to synthesize magnetite nanoparticles $\left(\mathrm{Fe}_{3} \mathrm{O}_{4}\right)$ by microwave-assisted hydrothermal method in a short processing time without further treatment is reported. The material obtained was tested as anode active material for lithium ions batteries. Impedance spectroscopy revealed that small differences in cell performance on cycling observed between samples cannot be strictly correlated to cell resistance. A high reversible capacity of $768.5 \mathrm{mAhg}^{-1}$ at $1 \mathrm{C}$ over 50 cycles was demonstrated, suggesting its prospective use as anode material for high power lithium ion batteries.
\end{abstract}

Keywords: magnetite, nanoparticles, Microwave hydrothermal (MH), Lithium ion batteries, anode active material

\section{Introduction}

Magnetite $\mathrm{Fe}_{3} \mathrm{O}_{4}$ is one of the most fascinating natural ore for technological and scientific reasons ${ }^{1}$. It is a magnetic iron oxide that presents an inverse spinel structure with face-centered cubic (FCC) unit cell, formed by oxide anions and iron cations occupying the tetrahedral and octahedral sites inside the structure ${ }^{2}$. The presence of iron ions in both divalent and trivalent oxidation states, provides several different applications of magnetite materials. The magnetic properties of magnetite nanoparticles have been intensively studied due to its relevance to magnetic recording and biomedical applications $\mathrm{s}^{3-5}$.

The large demand for energy storage devices has encouraged studies on rechargeable Li-ions batteries (LIBs). They have been widely used as high power source for several portable electronic devices and electric vehicles ${ }^{6-8}$. The research efforts have push up the interest in developing new electrode materials with high capacity and cycling stability for a new generation of lithium ion batteries. Numerous binary $\mathrm{M}_{\mathrm{x}} \mathrm{O}_{\mathrm{y}}$ compounds have been studied as low voltage working electrodes versus lithium $^{8,9}$ with the challenge of overcoming the limited capacity provided by graphite. Among these potential binary compounds, $\mathrm{Fe}_{3} \mathrm{O}_{4}$

*e-mail: mauricio.bomio@ct.ufrn.br deserves great attention for its high theoretical capacity (926 $\left.\mathrm{mAhg}^{-1}\right)$, low cost, being environmental-friendly and naturally abundant worldwide ${ }^{10-12}$

Several reports have proposed that conversion reactions in lithium ions batteries are affected by composition, particle size and morphology, which in turn are directly related to the preparation method of active materials ${ }^{13,14}$. The development and implementation of nanostructured materials has led to great improvements in Li-ion battery performance, since size reduction leads to improvements in the Li-ion battery intercalation capability by increasing the specific surface area for interfacial Faradaic reactions and the $\mathrm{Li}^{+}$flux across the electrode-electrolyte interface; these effects ultimately enhance the mass and charge diffusion paths and modify the thermodynamics (compared to bulk), which facilitates phase transitions ${ }^{15}$. Hydrothermal techniques are suitable for the synthesis of ultrafine materials with homogeneous composition and adequate morphology for use in multiple technological purposes. Microwave hydrothermal method (MH) combines the advantages of both hydrothermal and microwave-irradiation techniques such as very short reaction time, production of small particles with a narrow size distribution and high purity ${ }^{16}$. This method have been 
extensively used for the preparation of pure phase of several material with different applications such as, copper oxide $(\mathrm{CuO})^{17,18}$, zinc oxide $(\mathrm{ZnO})^{19-21}$ hafnium oxide $\left(\mathrm{HfO}_{2}\right)^{22}$ and cerium oxide $\left(\mathrm{CeO}_{2}\right)^{23,24}$.

In this paper, we report a simple strategy to synthesize magnetite nanoparticles $\left(\mathrm{Fe}_{3} \mathrm{O}_{4}\right)$ by microwave hydrothermal method in a short time of processing without further treatment. The material obtained was tested as anode active material for lithium ions batteries and a high reversible capacity of $768.5 \mathrm{mAhg}^{-1}$ at $1 \mathrm{C}$ over 50 cycles was demonstrated, suggesting its prospective use as anode material for high power lithium ion batteries.

\section{Results and Discussion}

Figure 1 shows the XRD patterns of the magnetite samples processed under microwave-assisted hydrothermal conditions for 8 and 15 min. Cubic $\mathrm{Fe}_{3} \mathrm{O}_{4}$ (JCPDS No. 19-629) was present in all samples. No secondary phase peaks were found in samples.

Figure 2 presents HRTEM and TEM images of $\mathrm{Fe}_{3} \mathrm{O}_{4}$ nanoparticles processed under microwave-assisted hydrothermal conditions for $15 \mathrm{~min}$. The TEM image in Figures $2 \mathrm{a}-\mathrm{b}$ indicates that the samples are mainly composed of nanoparticles with average size of $25 \mathrm{~nm}$. The analysis of

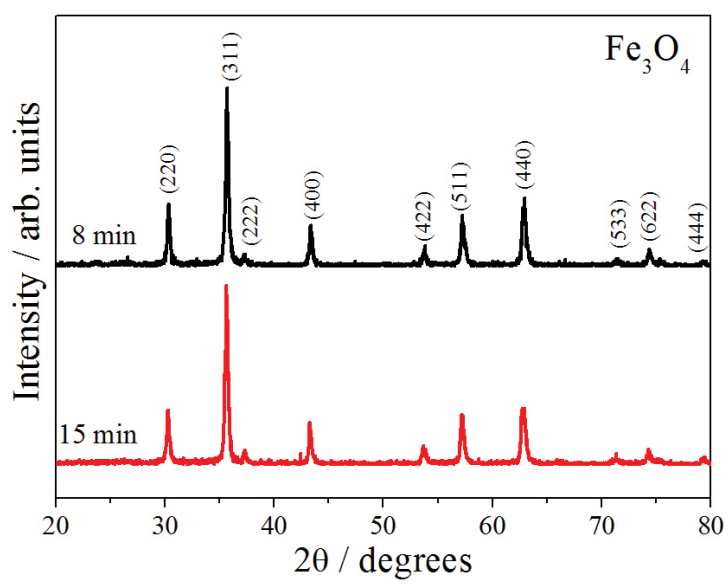

Figure 1. X-Ray diffraction patterns of $\mathrm{Fe}_{3} \mathrm{O}_{4}$ samples. the expanded HRTEM image inset in Figure 2c shows that the distance between neighboring planes is about $0.25 \mathrm{~nm}$, related to the (311) crystallographic plane of cubic $\mathrm{Fe}_{3} \mathrm{O}_{4}$.

In the initial $\mathrm{MH}$ processing stages, the microwave radiation is able to promote localized superheating in the aqueous solution as well as accelerate the solid particles to high velocities, leading to an increase of the interparticle collisions and inducing effective fusion at the point of collision. Moreover, this kind of electromagnetic energy can induce a uniform heating inside the primary particles formed after nucleation stage. In principle, all these effects caused by the microwave radiation favor the formation of aggregated particles with irregular shapes ${ }^{25}$.

The lithium storage mechanism of iron oxides here explored is based on redox conversion reaction. Iron oxides are completely reduced into mettalic $\mathrm{Fe}$ nanocrystals dispersed into the $\mathrm{Li}_{2} \mathrm{O}$ matrix upon lithiation and then reversibly restored to their initial oxidation states during delithiation $^{26}$. Figure 3 exhibits the voltage profiles of the first cycle of magnetite samples processed under microwaveassisted hydrothermal conditions for 8 and $15 \mathrm{~min}$. During the first discharge of $\mathrm{Fe}_{3} \mathrm{O}_{4}$ nanoparticles, the cell voltage decreases steeply to ca. $1.5 \mathrm{~V}$, being then followed by a small slope. When the voltage continues to decrease to ca. $1.0 \mathrm{~V}$, a short plateau appears, which delivers capacity of ca. $100 \mathrm{mAhg}^{-1}$. Then, the voltage continues to decrease to ca. $0.8 \mathrm{~V}$ until the appearance of an obvious large voltage plateau for ca. $800 \mathrm{mAhg}^{-1}$. Finally, a gradual voltage decrease is observed up to the cut-off value. Particularly, the short plateau that appears at $1.0 \mathrm{~V}$ is due to lithium intercalation into the $\mathrm{Fe}_{3} \mathrm{O}_{4}$ framework before the conversion reaction proceed. The large discharge plateau around $0.8 \mathrm{~V}$ appears in both $\mathrm{Fe}_{3} \mathrm{O}_{4}$ samples, which is in accordance with the reduction of $\mathrm{Fe}_{3} \mathrm{O}_{4}$ by lithium to the metallic state ${ }^{27}$. The gradual potential decay from ca. $0.8 \mathrm{~V}$ to the cut-off voltage has been ascribed to the reversible decomposition of the electrolyte and the partial formation of SEI layer on the surface of the $\mathrm{Fe}+\mathrm{Li}_{2} \mathrm{O}$ matrix ${ }^{27}$.

Besides the high capacity, rate capability is also important for the high performance of LIBs. Figure 4 shows the voltage profiles of $\mathrm{Fe}_{3} \mathrm{O}_{4}$ nanoparticles cycled at current rates of 1 and $2 \mathrm{C}$. The capacity of $\mathrm{Fe}_{3} \mathrm{O}_{4}$ nanoparticles on cycling showed two types of variation at current rate of $1 \mathrm{C}$ :

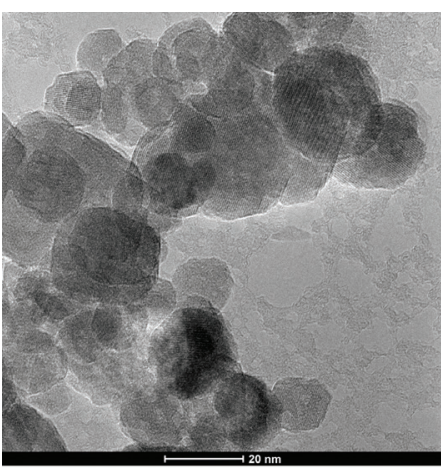

(a)

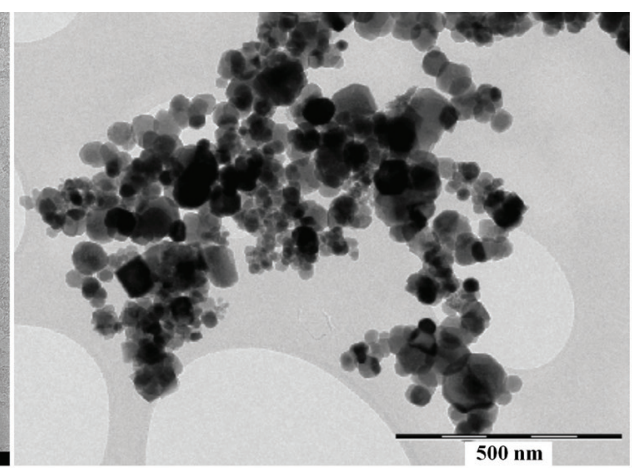

(b)

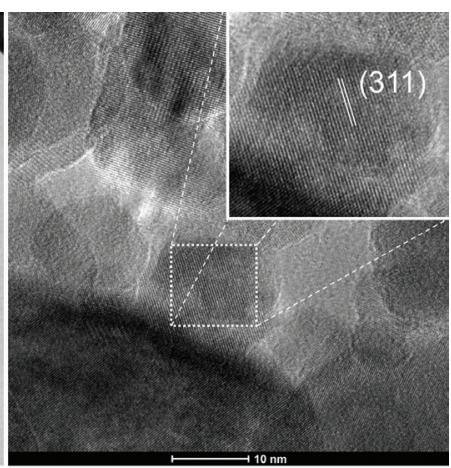

(c)

Figure 2. TEM (a-b) and HRTEM (c) images of $\mathrm{Fe}_{3} \mathrm{O}_{4}$ nanoparticles processed under microwave-assisted hydrothermal conditions for $15 \mathrm{~min}$. The inset shows crystallographic planes (c). 
for samples processed for $8 \mathrm{~min}$, the reversible capacity presented a slight increase up to the $9^{\text {th }}$ cycle followed by a continuous decay, whereas for samples processed for $15 \mathrm{~min}$ the reversible capacity remained constant up to the $10^{\text {th }}$ cycle followed by a continuous decay up to the last cycle. As the current rate increases to $2 \mathrm{C}$ the charge/discharge performance for sample processed for $8 \mathrm{~min}$ showed no significant change, while for those processed for $15 \mathrm{~min}$ a decrease in performance was observed.

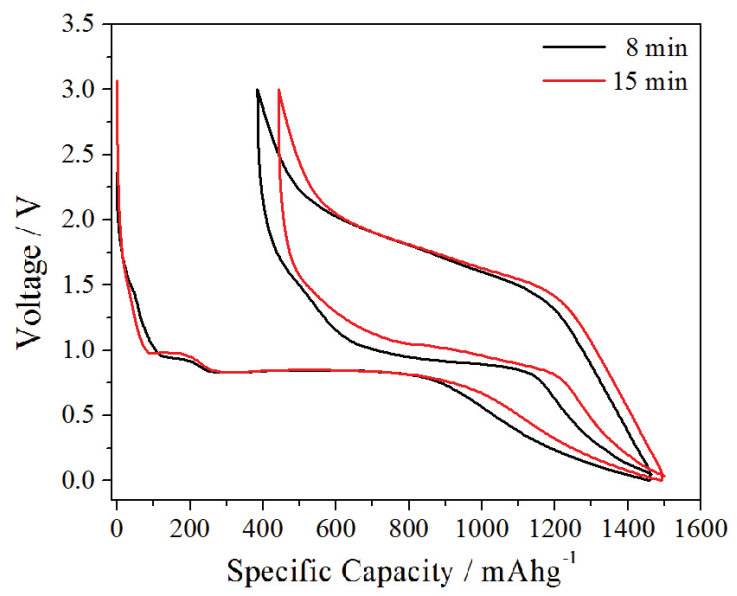

Figure 3. Voltage profiles of $\mathrm{Fe}_{3} \mathrm{O}_{4}$ nanoparticles at $1 \mathrm{C}$ rate.

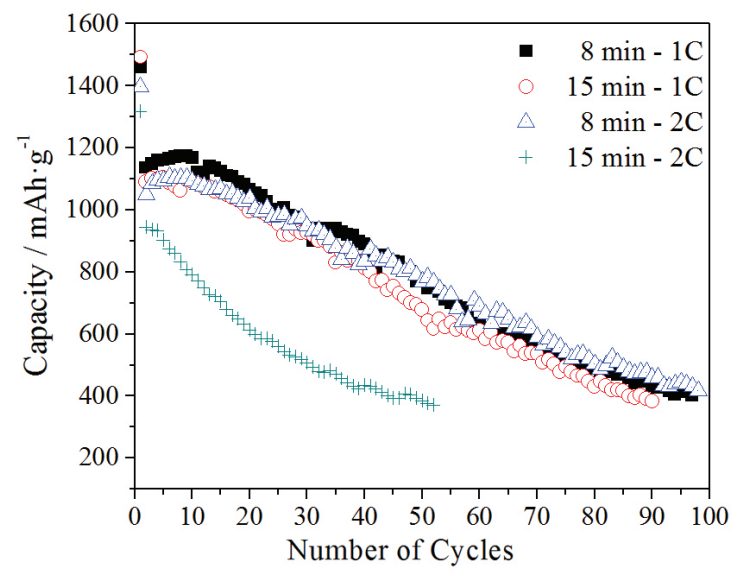

Figure 4. Discharge/charge cycling performance at different current densities of $\mathrm{Fe}_{3} \mathrm{O}_{4}$ nanoparticles.
In general, samples processed for $8 \mathrm{~min}$ were less influenced by the increased kinetic rate. Undoubtedly, their low particle size is likely to be directly related to this behavior. While for samples processed for $15 \mathrm{~min}$, the charge/discharge performance decreases with increasing kinetic rate, probably due to the kinetic hindering, caused by the growth of bulk particles during hydrothermal processing.

Comparing the performance of $\mathrm{Fe}_{3} \mathrm{O}_{4}$ nanoparticles with other reported ferrite-based anodes, shown in Table 1, it can be seen that the values for the first discharge capacity and the capacity retention after 50 cycles are higher for our samples than for most of other $\mathrm{Fe}_{3} \mathrm{O}_{4}$ based anodes. These results indicate that $\mathrm{Fe}_{3} \mathrm{O}_{4}$ nanoparticles presented in this study can be considered as a good choice of anodes for lithium ions batteries.

The internal cell resistance usually affects the electrochemical performance of electrode materials upon cycling. These parameters can be evaluated from the impedance spectra of electrodes. Figure 5 shows the Nyquist plots for cells assembled with the studied samples and after one, five and ten discharges. The profiles reveal two semicircles at high and intermediate frequencies. These features are commonly ascribed to the lithium migration through the surface layer and charge transfer reactions. The depression of semicircles reveals a frequency dispersion that must be described by a constant-phase element (CPE). The fitting of spectra according to the equivalent circuit in Figure $5 \mathrm{~b}$ allowed calculating the resistance values associated to the processes mentioned above (Table 2). The nearly linear-type frequency variation observed at low frequencies is fitted by introducing a Warburg component (W) describing the system response to the $\mathrm{Li}^{+}$diffusion through the iron oxide.

The results shown in Table 2 reveal that similar RSL values were recorded for both samples after the first discharge. On cycling, these values slightly increased. The most remarkable differences were observed for $\mathrm{R}_{\mathrm{CT}}$ values. Thus, the sample treated for 15 minutes showed significantly lower resistance values. These results could be explained by a lower content of surface defects which are removed during thermal treatment. Therefore, the differences in cell performance on cycling observed between samples cannot be strictly correlated to cell resistance. Most probably, other factors such as the crystallinity of pristine electrodes or the stability of the polymeric layer are essential to describe this behavior.

Table 1. Comparison of published literature data with that obtained in this work.

\begin{tabular}{|c|c|c|c|c|c|}
\hline Material & $\begin{array}{c}1^{\text {st }} \text { discharge capacity } \\
\left(\mathrm{mAhg}^{-1}\right)\end{array}$ & $\begin{array}{l}1^{\text {st }} \text { coulombic } \\
\text { efficiency }(\%)\end{array}$ & $\begin{array}{c}\mathrm{n}^{\text {th }} \text { discharge capacity } \\
\left(\mathrm{mAhg}^{-1}\right)\end{array}$ & $\begin{array}{c}\text { Capacity retention for } \\
\text { n cycles }(\%)\end{array}$ & Ref. \\
\hline $\mathrm{Fe}_{3} \mathrm{O}_{4} / \mathrm{C}$ composite & 775.0 & 71.9 & $197.0\left(100^{\text {th }}\right)$ & $32.0\left(100^{\text {th }}\right)$ & [27] \\
\hline Nano-sized $\mathrm{Fe}_{3} \mathrm{O}_{4}$ & 1083.1 & 77.0 & $353.50\left(50^{\text {th }}\right)$ & $32.6\left(5^{\text {th }}\right)$ & {$[28]$} \\
\hline Micro-sized $\mathrm{Fe}_{3} \mathrm{O}_{4}$ & 887.5 & 66.4 & $684.4\left(50^{\text {th }}\right)$ & $77.0\left(50^{\text {th }}\right)$ & [28] \\
\hline Urchin-like $\mathrm{Fe}_{3} \mathrm{O}_{4}$ & 1473.0 & 76.3 & $155.0\left(50^{\text {th }}\right)$ & $10.5\left(50^{\text {th }}\right)$ & [6] \\
\hline Commercial $\mathrm{Fe}_{3} \mathrm{O}_{4}$ & 1325.0 & 80.6 & $395.0\left(50^{\text {th }}\right)$ & $29.8\left(50^{\text {th }}\right)$ & {$[6]$} \\
\hline $\mathrm{Fe}_{3} \mathrm{O}_{4} / \mathrm{C}$ composite & 1550.0 & - & $702.0\left(50^{\text {th }}\right)$ & $45.3\left(50^{\text {th }}\right)$ & [29] \\
\hline$\alpha-\mathrm{Fe}_{2} \mathrm{O}_{3}$ nanorods & 1230.4 & 77.7 & $893.3\left(50^{\text {th }}\right)$ & $72.6\left(50^{\text {th }}\right)$ & [30] \\
\hline $\mathrm{Fe}_{3} \mathrm{O}_{4}$ nanoparticles & 1461.3 & 73.7 & $\begin{array}{l}768.5\left(50^{\text {th }}\right) \\
402.9\left(97^{\text {th }}\right)\end{array}$ & $\begin{array}{l}52.6\left(50^{\text {th }}\right) \\
27.6\left(97^{\text {th }}\right)\end{array}$ & $\begin{array}{c}\text { This } \\
\text { study }\end{array}$ \\
\hline
\end{tabular}




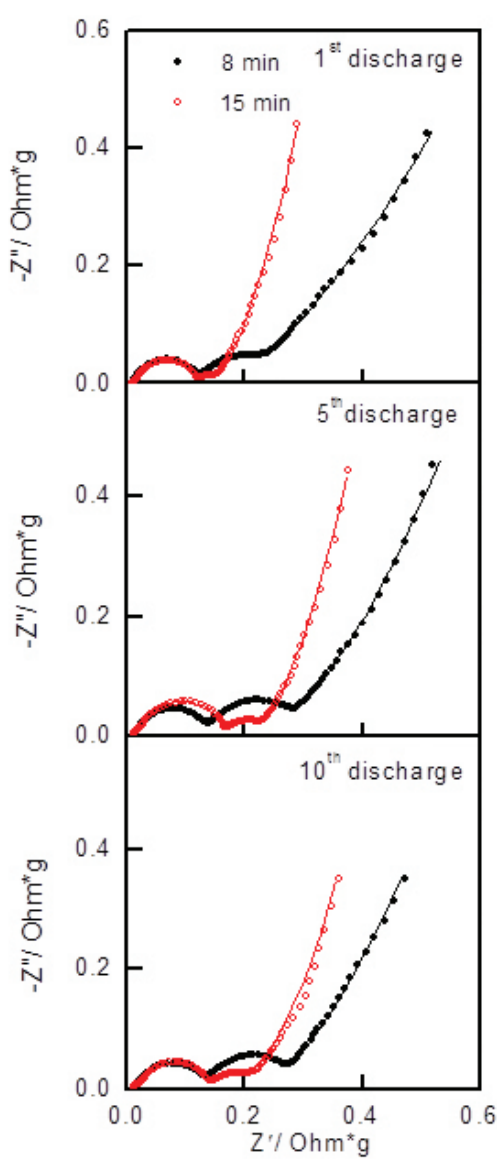

a

size of $25 \mathrm{~nm}$. When tested as the anode in lithium batteries, $\mathrm{Fe}_{3} \mathrm{O}_{4}$ nanoparticles exhibited a high reversible capacity, excellent cycling performance, and good capability rate. According to impedance spectroscopy, the differences in cell performance on cycling observed between samples can be due to the crystallinity of pristine electrodes or the stability of the polymeric layer. The results reported here are of interest with respect to possible applications.

\section{Experimental Section}

The chemical materials used here were all commercially available, and all of the chemical reagents were of analytical grade and used in this experiment without any further purification.

The typical procedure employed in order to obtain $\mathrm{Fe}_{3} \mathrm{O}_{4}$ nanoparticles was precipitation of the material and further microwave hydrothermal processing. In a becker, $\mathrm{FeSO}_{4} \cdot 7 \mathrm{H}_{2} \mathrm{O}$ was dissolved in deionized water with finally concentration $0.04 \mathrm{~mol} . \mathrm{L}^{-1}$ and stirring for 15 minutes. Then, the previous solution was neutralized by the addition of mineralizing agent ammonium hydroxide with concentration of $1 \mathrm{M}$, then, the black precipitated was obtained. These resulting materials were sealed in a $100 \mathrm{ml}$ Teflon lined autoclave and treated by microwave hydrothermal procedure for 8 and 15 minutes at $100^{\circ} \mathrm{C}$. The black products were washed several times with deionized water and separated by centrifugation until total removal of the mineralizing agent and dried in conventional furnace at $60^{\circ} \mathrm{C}$ for some hours.

The $\mathrm{Fe}_{3} \mathrm{O}_{4}$ powders were structurally characterized by X-ray diffraction (XRD) patterns using a DMax/2500PC diffractometer (Rigaku, Japan) with $\mathrm{Cu} \mathrm{K} \alpha$ radiation $(\lambda=1.5406 \AA)$ in the $2 \theta$ range from $20^{\circ}$ to $80^{\circ}$ with scanning rate of $0.2 \%$. The morphologies were investigated through a FEG-SEM of Carl Zeiss, model Supra 35-VP (Germany), operated at $6 \mathrm{kV}$ and a transmission electron microscope (TEM), model CM200 (Philips, USA), operated at $200 \mathrm{kV}$. In the preparation of TEM samples, the obtained powders were first dispersed in acetone using ultrasonic bath for 20 minutes. Then, the suspensions were deposited on copper grids via fast immersion.

Electrochemical tests were performed in two and three electrodes Swagelok-type cells were assembled inside a MBraun LabMaster 130 glove box under argon atmosphere with less than 2 ppm of $\mathrm{H}_{2} \mathrm{O}$ and $\mathrm{O}_{2}$. Lithium metal disk of $9 \mathrm{~mm}$ in diameter, was used as auxiliary and reference. The electrolyte solution (1 $\mathrm{M} \mathrm{LiPF}_{6}$ in 1:1/EC:DEC) was supported by two porous glass-paper (GF/A-Whatman) disks also acting as separator. Electrodes containing the studied samples were fabricated from a mixture containing $75 \%$ active material, $10 \%$ carbon black, $10 \%$ graphite, and $5 \%$ polyvinylidene fluoride (PVDF). A paste was prepared by soaking this mixture in -methyl-2-pyrrolidone (NMP) which is eventually spread onto a 9-mm diameter copper foil (Good fellow 99.999\%). The electrode was dried at $120^{\circ} \mathrm{C}$ and $7 \mathrm{mbar}$ for $4 \mathrm{~h}$ and pressed under 1 ton load to ensure uniform surface. Galvanostatic battery testing was carried out in two Li/1M LiPF 6 (EC:DEC)/ $\mathrm{Fe}_{3} \mathrm{O}_{4}$ electrodes. Current control and cell potential measurements during charge and discharge were carried out with a multichannel galvanostat. This equipment controls current conditions during charging phases were not observed. TEM images that these samples consist of nanoparticles with average 
and discharging and monitors cell potential and test time. Moreover, Electrochemical Impedance Spectra (EIS) were recorded from three electrode Swagelok-type cells. The test cell was previously discharged to a definite depth and let to relax for 5 hours. The AC measurements were made in AUTOLAB PGSTAT 12 with a $5 \mathrm{mV}$ amplitude and frequency range from $100 \mathrm{kHz}$ to $10 \mathrm{mHz}$.

\section{References}

1. Rozenberg GK, Amiel Y, Xu W, Pasternak M, Jeanloz R, Hanfland $M$ et al. Structural characterization of temperatureand pressure-induced inverse $\leftrightarrow$ normal spinel transformation in magnetite. Physical Review B: Condensed Matter and Materials Physics. 2007; 75(2):020102-020104. http://dx.doi. org/10.1103/PhysRevB.75.020102.

2. Sun S and Zeng H. Size-controlled synthesis of magnetite nanoparticles. Journal of the American Chemical Society. 2002; 124(28):8204-8205. http://dx.doi.org/10.1021/ja026501x. PMid:12105897

3. Raj K and Moskowitz R. Commercial applications of ferrofluids. Journal of Magnetism and Magnetic Materials. 1990; 85(1-3):233-245. http://dx.doi.org/10.1016/03048853(90)90058-X.

4. Ito A, Shinkai M, Honda H and Kobayashi T. Medical application of functionalized magnetic nanoparticles. Journal of Bioscience and Bioengineering. 2005; 100(1):1-11. http:// dx.doi.org/10.1263/jbb.100.1. PMid:16233845

5. Shinkai M. Functional magnetic particles for medical application. Journal of Bioscience and Bioengineering. 2002; 94(6):606-613. http://dx.doi.org/10.1016/S13891723(02)80202-X. PMid:16233357

6. Hao Q, Lei D, Yin X, Zhang M, Liu S, Li Q et al. 3-D mesoporous nano/micro-structured $\mathrm{Fe}_{3} \mathrm{O}_{4} / \mathrm{C}$ as a superior anode material for lithium-ion batteries. Journal of Solid State Electrochemistry. 2011; 15(11-12):2563-2569. http://dx.doi. org/10.1007/s10008-010-1232-4.

7. Ban C, Wu Z, Gillaspie DT, Chen L, Yan Y, Blackburn JL et al. Nanostructured $\left.\mathrm{Fe}\left({ }_{3}\right) \mathrm{O}_{4}\right) /$ SWNT electrode: Binder-free and high-rate li-ion anode. Advanced Materials. 2010; 22(20):E145-E149. http://dx.doi.org/10.1002/ adma.200904285. PMid:20440701

8. Taberna PL, Mitra S, Poizot P, Simon P and Tarascon J-M. High rate capabilities $\mathrm{Fe}_{3} \mathrm{O}_{4}$-based $\mathrm{Cu}$ nano-architectured electrodes for lithium-ion battery applications. Nature Materials. 2006; 5(7):567-573. http://dx.doi.org/10.1038/nmat1672. PMid: 16783360

9. Poizot P, Laruelle S, Grugeon S, Dupont L and Tarascon J-M. Nano-sized transition-metal oxides as negativeelectrode materials for lithium-ion batteries. Nature. 2000; 407(6803):496-499. http://dx.doi.org/10.1038/35035045. PMid:11028997

10. Zhang W-M, Wu X-L, Hu J-S, Guo Y-G and Wan L-J. Carbon Coated $\mathrm{Fe}_{3} \mathrm{O}_{4}$ Nanospindles as a Superior Anode Material for Lithium-Ion Batteries. Advanced Functional Materials. 2008; 18(24):3941-3946. http://dx.doi.org/10.1002/adfm.200801386.

11. Muraliganth T, Vadivel Murugan A and Manthiram A. Facile synthesis of carbon-decorated single-crystalline $\mathrm{Fe}_{3} \mathrm{O}_{4}$ nanowires and their application as high performance anode in lithium ion batteries. Chemical Communications. 2009; 0(47):7360-7362. http://dx.doi.org/10.1039/b916376j. PMid:20024228

\section{Acknowledgements}

The authors thank the financial support from the following Brazilian research financing institutions: CAPES, FAPESP 2013/07296-2, INCTMN 2008/57872-1 and CNPq 573636/2008-7, CNPq Universal 14/2011 481288/2011-2, Junta de Andalucía (Spain) FQM-6017 for their financial support.

12. Liu H, Wang G, Wang J and Wexler D. Magnetite/carbon coreshell nanorods as anode materials for lithium-ion batteries. Electrochemistry Communications. 2008; 10(12):1879-1882. http://dx.doi.org/10.1016/j.elecom.2008.09.036.

13. Bomio M, Lavela $P$ and Tirado JL. Electrochemical evaluation of $\mathrm{CuFe}_{2} \mathrm{O}_{4}$ samples obtained by sol-gel methods used as anodes in lithium batteries. Journal of Solid State Electrochemistry. 2008; 12(6):729-737. http://dx.doi.org/10.1007/s10008-0070420-3.

14. Lavela P, Ortiz GF, Tirado JL, Zhecheva E, Stoyanova R and Ivanova S. High-Performance Transition Metal Mixed Oxides in Conversion Electrodes: A Combined Spectroscopic and Electrochemical Study. The Journal of Physical Chemistry C. 2007; 111(38):14238-14246. http://dx.doi.org/10.1021/ jp074142s.

15. Uchaker E, Gu M, Zhou N, Li Y, Wang C and Cao G. Enhanced intercalation dynamics and stability of engineered micro/nanostructured electrode materials: vanadium oxide mesocrystals. Small. 2013; 9(22):3880-3886. http://dx.doi.org/10.1002/ smll.201203187. PMid:23650258

16. Komarneni S. Nanophase materials by hydrothermal, microwave-hydrothermal and microwave-solvothermal methods. Current Science. 2003; 85(12):1730-1734.

17. Keyson D, Volanti DP, Cavalcante LS, Simões AZ, Varela JA and Longo E. CuO urchin-nanostructures synthesized from a domestic hydrothermal microwave method. Materials Research Bulletin. 2008; 43(3):771-775. http://dx.doi.org/10.1016/j. materresbull.2007.03.019.

18. Moura AP, Cavalcante LS, Sczancoski JC, Stroppa DG, Paris EC, Ramirez AJ et al. Structure and growth mechanism of $\mathrm{CuO}$ plates obtained by microwave-hydrothermal without surfactants. Advanced Powder Technology. 2010; 21(2):197202. http://dx.doi.org/10.1016/j.apt.2009.11.007.

19. Lima RC, Macario LR, Espinosa JW, Longo VM, Erlo R, Marana NL et al. Toward an understanding of intermediateand short-range defects in $\mathrm{ZnO}$ single crystals. A combined experimental and theoretical study. The Journal of Physical Chemistry A. 2008; 112(38):8970-8978. http://dx.doi. org/10.1021/jp8022474. PMid:18652436

20. de Moura AP, Lima RC, Moreira ML, Volanti DP, Espinosa JWM, Orlandi MO et al. $\mathrm{ZnO}$ architectures synthesized by a microwave-assisted hydrothermal method and their photoluminescence properties. Solid State Ionics. 2010; 181(1516):775-780. http://dx.doi.org/10.1016/j.ssi.2010.03.013.

21. Milao TM, de Mendonça VR, Araújo VD, Avansi W, Ribeiro C, Longo E et al. Microwave Hydrothermal Synthesis and Photocatalytic Performance of $\mathrm{ZnO}$ and $\mathrm{M}: \mathrm{ZnO}$ Nanostructures ( $\mathrm{M}=\mathrm{V}, \mathrm{Fe}, \mathrm{Co})$. Science of Advanced Materials. 2012; 4(1):5460. http://dx.doi.org/10.1166/sam.2012.1251.

22. Eliziário SA, Cavalcante LS, Sczancoski JC, Pizani PS, Varela JA, Espinosa JW et al. Morphology and photoluminescence of $\mathrm{HfO}_{2}$ obtained by microwave-hydrothermal. Nanoscale Research Letters. 2009; 4(11):1371-1379. http://dx.doi. org/10.1007/s11671-009-9407-6. PMid:20628455 
23. Dos Santos ML, Lima RC, Riccardi CS, Tranquilin RL, Bueno PR, Varela JA, et al. Preparation and characterization of ceria nanospheres by microwave-hydrothermal method. Materials Letters. 2008; 62(30):4509-4511. http://dx.doi.org/10.1016/j. matlet.2008.08.011.

24. Araujo VD, Avansi W, de Carvalho HB, Moreira ML, Longo E, Ribeiro $\mathrm{C}$ et al. $\mathrm{CeO}_{2}$ nanoparticles synthesized by a microwave-assisted hydrothermal method: evolution from nanospheres to nanorods. CrystEng Comm. 2012; 14(3):11501154. http://dx.doi.org/10.1039/c1ce06188g.

25. Xavier CS, Sczancoski JC, Cavalcante LS, Paiva-Santos $\mathrm{CO}$, Varela JA, Longo $\mathrm{E}$ et al. A new processing method of $\mathrm{CaZn} 2(\mathrm{OH})_{6}: 2 \mathrm{H}_{2} \mathrm{O}$ powders: Photoluminescence and growth mechanism. Solid State Sciences. 2009; 11(12):2173-2179. http://dx.doi.org/10.1016/j.solidstatesciences.2009.09.002.

26. Gao G, Qiu P, Qian Q, Zhou N, Wang K, Song H, et al. PEG200-assisted hydrothermal method for the controlled-synthesis of highly dispersed hollow $\mathrm{Fe}_{3} \mathrm{O}_{4}$ nanoparticles. Journal of Alloys and Compounds. 2013; 574(0):340-344. http://dx.doi. org/10.1016/j.jallcom.2013.05.050.
27. Wang P, Gao M, Pan H, Zhang J, Liang C, Wang J et al. A facile synthesis of $\mathrm{Fe}_{3} \mathrm{O}_{4} / \mathrm{C}$ composite with high cycle stability as anode material for lithium-ion batteries. Journal of Power Sources. 2013; 239(0):466-474. http://dx.doi.org/10.1016/j. jpowsour.2013.03.073.

28. Chen YX, He LH, Shang PJ, Tang QL, Liu ZQ, Liu HBu et al. Micro-sized and Nano-sized $\mathrm{Fe}_{3} \mathrm{O}_{4}$ Particles as Anode Materials for Lithium-ion Batteries. Journal of Materials Science and Technology. 2011; 27(1):41-45. http://dx.doi.org/10.1016/ S1005-0302(11)60023-6.

29. Latorre-Sanchez M, Primo A and Garcia H. Green synthesis of $\mathrm{Fe}_{3} \mathrm{O}_{4}$ nanoparticles embedded in a porous carbon matrix and its use as anode material in Li-ion batteries. Journal of Materials Chemistry. 2012; 22(40):21373-21375. http://dx.doi. org/10.1039/c2jm34978g.

30. Xiao Z, Xia Y, Ren Z, Liu Z, Xu G, Chao C et al. is Facile synthesis of single-crystalline mesoporous $\alpha-\mathrm{Fe}_{2} \mathrm{O}_{3}$ and $\mathrm{Fe}_{3} \mathrm{O}_{4}$ nanorods as anode materials for lithium-ion batteries. Journal of Materials Chemistry. 2012; 22(38):20566-20573. http:// dx.doi.org/10.1039/c2jm34083f. 